\title{
ODPOWIEDZIALNOŚĆ SPOŁECZNA JAKO STRATEGIA PRZYWÓDZTWA PRZEDSIĘBIORSTWA NA RYNKU
}

\section{Abstract}

\section{Social Responsibility as a Strategy of Market Leadership}

The article presents the relationship between corporate social responsibility, corporate image, and leadership in the context of globalization. It has been proven that market leadership has different sources of the formation. The internal manifestation is formed due to the orientation of social responsibility on the employees of the company, while the external manifestation is created because of the focus on business partners, customers, and society. The features of social responsibility within the business strategy are presented. The system of advantages for socially responsible companies has analyzed in the short- and longterm. Attention is paid to the factors that limit the social activity of companies. The author proved the need to expand the information space with the intention of publishing trends and results of companies' social activity. The stages of developing and disseminating social reports of companies were proposed. It justified the benefits that the company receives through the use of social reporting.

Keywords: corporate social responsibility, corporate strategy, market leadership, business environment, competitive advantages

\section{Streszczenie}

W artykule przedstawiono relacje między odpowiedzialnością społeczną, wizerunkiem i przywództwem przedsiębiorstw w kontekście globalizacji. Udowodniono, że przywództwo na rynku ma różne źródła. PW aspekcie wewnętrznym przejawia się przez zorientowanie odpowiedzialności społecznej na pracowników przedsiębiorstwa, w aspekcie zewnętrznym natomiast jest tworzone ze względu na koncentrację na partnerów biznesowych, klientów i społeczeństwo. Zaprezentowano cechy odpowiedzialności społecznej w ramach strategii biznesowej. Przeanalizowano przewagi przedsiębiorstw odpowiedzialnych społecznie w perspektywie krótko- i długoterminowej. Zwrócono uwagę na czynniki, które ograniczają społeczną aktywność przedsiębiorstw. Uzasadniono potrzebę rozszerzenia przestrzeni informacyjnej z zamiarem publikowania trendów i wyników społecznej aktywności przedsiębiorstw. Zaproponowano 
etapy opracowywania i rozpowszechniania społecznych raportów przedsiębiorstw. Uzasadniono korzyści, które przedsiębiorstwo otrzymuje w procesie wykorzystywania raportowania społecznego.

Słowa kluczowe: odpowiedzialność społeczna, strategia przedsiębiorstwa, przywództwo na rynku, otoczenie biznesu, przewagi konkurencyjne

\section{Wstęp}

W kontekście globalizacji wizerunek przedsiębiorstwa odgrywa istotną rolę w rozwoju i tworzeniu przywództwa przedsiębiorstwa na rynku. W związku z tym, odpowiedzialność społeczna wymaga szczególnej uwagi, ponieważ może zwiększyć kapitalizację przedsiębiorstw, zapewnia im przewagę konkurencyjną i daje możliwość pracy podczas zmiany transformacyjnej społeczeństwa. Jednocześnie odpowiedzialność społeczna potrafi pogodzić interesy rządu, biznesu i społeczeństwa w celu zapewnienia lojalności konsumentów, kontrahentów i pracowników. Dlatego odpowiedzialność społeczna powinna być częścią strategii biznesowej dla przedsiębiorstwa zwycięskiego.

\section{Materiał i metody}

Definicja odpowiedzialności społecznej pojawiła się w naukowych dyskusjach amerykańskich i europejskich naukowców w ostatnim trzydziestoleciu XX wieku. Interpretacja terminu, zdaniem naukowców z Uniwersytetu Ekonomicznego w Krakowie [Teczke i in., 2011], została podzielona na dwie grupy: procesowa - rozumienie odpowiedzialności jako swego rodzaju relacji; atrybutowa - rozumienie odpowiedzialności jako cechy (zachowania, postawy). Brytyjscy naukowcy podkreślają, że działalność w dziedzinie odpowiedzialności społecznej zazwyczaj koncentruje się na przedsiębiorstwach działających w krajach rozwiniętych [Frynas i in., 2016]. Znaczący wpływ na popularyzację koncepcji miały takie inicjatywy międzynarodowe, jak III Światowy Kongres przedsiębiorców i menedżerów (Davos, 1973), Konferencja Narodów Zjednoczonych w sprawie środowiska i rozwoju (Rio de Janeiro, 1992), ONZ Global Compact (1999), dokumenty Komisji Europejskiej („Zielona Księga”, 2001) itp. Badanie relacji odpowiedzialności społecznej i przywództwa na rynku nie jest jednak wystarczająco przetwarzane.

W związku z tym celem artykułu jest uzasadnienie teoretycznych i metodologicznych zasad relacji odpowiedzialności społecznej i przywództwa przedsiębiorstwa na rynku.

Podstawą metodologiczną artykułu są badania znanych naukowców, wyniki badań własnych, analiza głównych międzynarodowych technologii odpowiedzialności społecznej, aspekty ekonomiczne formowania praktyki społecznej 
odpowiedzialności przedsiębiorstw jako części strategii biznesowych oraz główne międzynarodowe standardy odpowiedzialności społecznej. Aby osiągnąć zamierzony cel, zastosowano metody dialektyczną, historyczną, logiczną oraz systematyczną.

\section{Wyniki}

\section{Relacje między odpowiedzialnością społeczną, wizerunkiem i przywództwem przedsiębiorstw w kontekście globalizacji}

W obecnych warunkach turbulentnych należy wypracować nowy typ myślenia zarówno przedsiębiorstw, jak i społeczeństwa. Powstawanie koncepcji biznesu odpowiedzialnego powoduje konieczność zwrócenia większej uwagi na kwestię wsparcia społecznego pracowników, społeczności lokalnej, środowiska. Amerykański badacz Howard R. Bowen [1953] podkreślił, że społeczna odpowiedzialność biznesmena to bardzo pożądany wzór zachowania z punktu widzenia celów i wartości społeczeństwa. Jego monografia Społeczna odpowiedzialność biznesmena wywołała falę badań w zakresie interakcji między biznesem a społeczeństwem. Keith Davis [1960] pierwszy udowodnił, że kwestię odpowiedzialności społecznej należy traktować zarówno w kontekście zarządzania, jak i w kontekście społecznym. Podkreślił, że taka odpowiedzialność jest tworzona na podstawie decyzji i działań przedsiębiorców, które przynajmniej częściowo wychodzą poza ramy bezpośredniego interesu gospodarczego lub technicznego przedsiębiorstw, i zapewniają wspaniałą okazję do uzyskania długoterminowego efektu gospodarczego przedsiębiorstw [Davis, 1960]. Dlatego menedżerowie powinni przestać polegać na tradycyjnej strategii, która koncentruje się wyłącznie na rozwoju gospodarczym i maksymalizacji zysków [Friedman, 1970]. Ewolucja koncepcji odpowiedzialności społecznej, sformułowanie dla działalności przedsiębiorstw nowych wymagań, które koncentrują się na zbieżności interesów producentów, konsumentów i społeczeństwa jako całości, spowodowane są stałym wzrostem stopnia dojrzałości gospodarki rynkowej, wzmocnieniem jej mechanizmów regulacyjnych i tworzeniem nowoczesnej ekonomii zorientowanej na społeczeństwo. Współczesne społeczeństwo stopniowo się zmienia i podąża w kierunku nowego paradygmatu odpowiedzialności przedsiębiorstw wobec niego, intensywnej interakcji ze społecznościami lokalnymi, racjonalnego wykorzystania zasobów naturalnych oraz potrzeby rozwijania zasobów ludzkich i tworzenia raportów społecznych. Środowisko biznesu zmienia się coraz szybciej, świadomość konsumentów stale wzrasta. Należy się więc zastanowić nad kwestią, które przedsiębiorstwa mogą być liderami w tych warunkach. Ponieważ zachowanie lidera wpływa na ogólną szybkość i kierunek rozwoju rynku, jest on w stanie wpływać na inne przedsiębiorstwa, aby zachęcić je do opracowywania i realizacji celów ważnych społecznie. Ze względu na rosnące ryzyko związane z niepewnością i szybkie zmiany liderzy na rynku potrafią kształtować wizję, podejmować 
niekonwencjonalne decyzje, inspirować pracowników do wzmożonego wysiłku. To właśnie dzięki koncepcji zarządzania opartego na przywództwie przedsiębiorstwa mogą sobie poradzić ze zmianami i kryzysami.

Jedną z najbardziej skutecznych strategii przywództwa na rynku jest społeczna odpowiedzialność biznesu. Jednocześnie przywództwo na rynku ma różne źródła. $\mathrm{W}$ aspekcie wewnętrznym przejawia się przez zorientowanie odpowiedzialności społecznej na pracowników przedsiębiorstwa: program rozwoju i szkoleń, opieka zdrowotna i ubezpieczenie, formowanie kultury korporacyjnej oraz tożsamości w przedsiębiorstwie, różne programy mające na celu wypoczynek. W aspekcie zewnętrznym polega na skierowaniu odpowiedzialności społecznej na:

- partnerów biznesowych (zgodność z dobrą reputacją przedsiębiorstwa);

- konsumentów (programy do poprawy jakości produktów, reklama społeczna);

- społeczeństwo (wytwarzanie społecznie istotnych produktów i usług; korzystanie z surowców wtórnych w cyklu technologicznym; programy środowiskowe, edukacyjne i badawcze; programy współpracy z władzami lokalnymi; programy wsparcia sportu, kultury i sztuki; mecenat i sponsorowanie).

Aktywna pozycja społeczna i wieloletnie doświadczenie działań odpowiedzialnych społecznie tworzą obraz, który został zbudowany w umysłach grup docelowych dzięki pozytywnemu wizerunkowi przedsiębiorstwa i oparty na korzyściach i cechach jego działalności. W sytuacji wysokiej konkurencji odpowiedzialność społeczna, pozytywny wizerunek i widoczność pozwalają przedsiębiorstwu odróżniać się efektywnie od konkurentów. W kontekście globalizacji i otwartości gospodarek narodowych można zidentyfikować kilka czynników, które zachęcają do rozwoju i rozpowszechniania społecznej orientacji biznesowych strategii przedsiębiorstw:

- zwiększenie dostępu do szerokiej gamy środków inwestycyjnych (powstało pojęcie inwestowania odpowiedzialnego społecznie; inwestorzy coraz bardziej zwracają uwagę na kwestie etyczne przy inwestowaniu w papiery wartościowe);

- rozbudowa istniejących i wejście na nowe rynki (bardziej atrakcyjny jest pomysł połączenia rentowności przedsiębiorstw z korzyściami dla społeczeństwa);

- przyciąganie wysoko wykwalifikowanych pracowników (ciągła poprawa warunków pracy pracowników w celu zwiększenia ich lojalności, wydajności i kreatywności).

Oferowany model wpływu odpowiedzialności społecznej na tworzenie wizerunku i przywództwo przedsiębiorstwa na rynku został pokazany na rysunku 1. Pojęcie społeczna odpowiedzialność przedsiębiorstwa jest czynnikiem nowoczesnego rozwoju gospodarczego i ma rosnące znaczenie społeczne. 


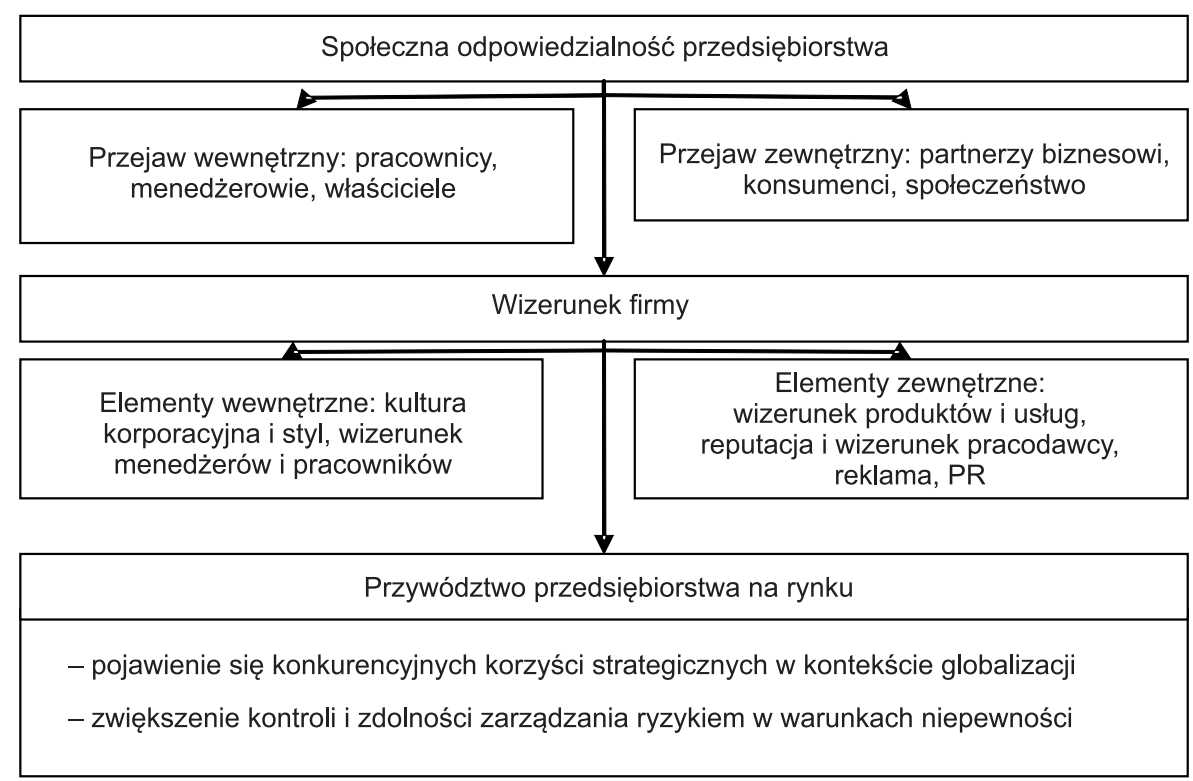

Rysunek 1. Model wpływu odpowiedzialności społecznej na tworzenie wizerunku i przywództwa przedsiębiorstwa na rynku

Źródło: opracowanie własne

\section{Cechy odpowiedzialności społecznej w ramach strategii biznesowej}

Odpowiedzialność społeczna przedsiębiorstw jest pojęciem wieloaspektowym, ponieważ ma szerokie znaczenie: odpowiedzialność wewnętrzna (pracownicy i właściciele) i zewnętrzna (klienci, kontrahenci, państwo i społeczeństwo). Odpowiedzialność społeczna jest związana z obecnością społecznie świadomych przedsiębiorstw i społeczności w kraju. Światowa Rada Biznesu na rzecz Zrównoważonego Rozwoju (World Business Council for Sustainable Development - WBCSD) definiuje społeczną odpowiedzialność biznesu jako „zobowiązanie biznesu do przyczyniania się do zrównoważonego gospodarczego rozwoju, współpracując z pracownikami, ich rodzinami, społecznością lokalną i całym społeczeństwem w celu poprawy jakości życia" [WBCSD]. Kwestia odpowiedzialności społecznej przedsiębiorstw jest regulowana przez system standardów:

- ISO 9000 „Zarządzanie jakością” (pomaga przedsiębiorstwu być bardziej efektywnym, zwiększyć satysfakcję klientów, poprawić reputację, przyciągnąć nowych klientów);

- System środowiskowego zarządzania i audytu Unii Europejskiej (zwiększenie wiarygodności, przejrzystości i reputacji; zmniejszenie zagrożeń środowiska; polepszenie relacji z klientami, społecznością lokalnej; poprawa upodmiotowienia pracowników i ich motywacji); 
- ISO 14000 „System zarządzania środowiskowego” (zapewnia praktyczne narzędzia dla przedsiębiorstw chcących zarządzać swoimi działaniami w zakresie ochrony środowiska);

- SA 8000 „Odpowiedzialność społeczna” (standardy certyfikacji społecznej dla godnej pracy we wszystkich sektorach przemysłowych);

- AA 1000 „System jakości raportowania” (zasady pomocy przedsiębiorstwom, które stają się bardziej odpowiedzialne i zrównoważone);

- Globalna inicjatywa raportowania (międzynarodowa niezależna organizacja, która pomaga przedsiębiorstwom rozumieć wpływ biznesu na zrównoważony rozwój);

- OHSAS 18000 „Zarządzanie w zakresie zdrowia i bezpieczeństwa” (pomaga zminimalizować ryzyko dla pracowników, zyskać pewność itp.).

Standardy regulują głównie środowiskowe aspekty odpowiedzialności społecznej, a także programy dotyczące pracowników. Próby generowania uniwersalnej koncepcji społecznej odpowiedzialności biznesu zostały odzwierciedlone w standardzie ISO 26000, zaproponowanym przez Międzynarodową Organizację Normalizacyjną. ISO 26000 uwzględnia przepisy wymienionych standardów w celu zapewnienia kompatybilności z innymi systemami, które są potrzebne szerokiej gamie użytkowników. Standard określa sposób realizacji strategicznych celów społecznej odpowiedzialności biznesu (ISO 26000):

- wytwarzanie wysokiej jakości produktów i usług dla konsumentów;

- inwestowanie w produkcję i potencjał ludzki;

- ścisłe przestrzeganie prawodawstwa;

- budowanie dobrosąsiedzkich i wzajemnie korzystnych relacji z interesariuszami;

- koncepcja biznesowa, która koncentruje się na zwiększeniu konkurencyjności krajowej;

- uwzględnienie oczekiwań społeczeństwa i przyjętych etycznych praktyk biznesowych;

- tworzenie społeczeństwa obywatelskiego w ramach programów partnerskich, projektów rozwoju społecznego.

Brytyjscy naukowcy w pracy zbiorowej [Crane i in., 2009] określili odpowiedzialność społeczną jako społeczne zobowiązanie i pozytywny wpływ korporacji na społeczeństwo. Europejscy ekonomiści uważają, że odpowiedzialność społeczna jest balansowaniem między korzyściami ekonomicznymi i interesami społeczeństwa [por. Ihlen, 2011]. Naukowcy z Międzynarodowego Instytutu Zrównoważonego Rozwoju, John Drexhage i Deborah Murphy [2010], dali uogólnioną interpretację odpowiedzialności społecznej jako dobrowolne inicjatywy prywatne, które wspierają ideę zrównoważonego rozwoju. Ogólnie rzecz ujmując, analiza istoty odpowiedzialności społecznej w pracach naukowych wskazuje na dwa aspekty:

- odpowiedzialność społeczna jako dobrowolny wkład biznesu na rzecz społeczeństwa;

- długoterminowe zobowiązanie biznesu w społeczeństwie. 
Można też jednak wziąć pod uwagę strategię odpowiedzialności społecznej jako przywództwa na rynku. Obiektywna potrzeba zachęcenia przedsiębiorstw do zagwarantowania bezpieczeństwa społecznego i ochrony socjalnej w społeczeństwie, wraz z jednoczesną potrzebą przedsiębiorstw formowania pozycji przywództwa na rynku, prowadzą do wzrostu inwestowania odpowiedzialnego społecznie. Według raportów rocznych zatem przedsiębiorstwa najbardziej aktywne społecznie są liderami na rynku: Microsoft, Google, The Walt Disney Company, BMW, Apple, Daimler (Mercedes-Benz), Volkswagen, Sony, Colgate-Palmolive, LEGO Group [10 Companies with the Best CSR Reputations].

Uważam, że dążenie do zajęcia pozycji lidera i zwiększenia kapitalizacji rynkowej przedsiębiorstwa powinno zwiększyć wartość odpowiedzialności społecznej jako strategii, która zapewnia przewagę konkurencyjną. System zalet przedsiębiorstw odpowiedzialnych społecznie to:

1) W perspektywie krótkoterminowej:

- rozszerzenie możliwości przyciągania oraz motywowania pracowników;

- zwiększenie lojalności klientów;

- ustanowienie dobrych stosunków z innymi przedsiębiorstwami, agencjami rządowymi i organizacjami pozarządowymi.

2) $\mathrm{W}$ perspektywie długoterminowej:

- formowanie reputacji, marki korporacyjnej, atrakcyjnego wizerunku przedsiębiorstwa dla konsumentów, środowiska biznesowego i społeczeństwa;

- poprawienie wyników finansowych i wzrost kapitalizacji przedsiębiorstw;

- poprawa jakości zarządzania ryzykiem (ekonomicznym, rynkowym, technologicznym, konkurencyjnym, społecznym itp.);

- podniesienie udziału przedsiębiorstwa w rynku i posiadanie pozycji przywództwa na rynku przez świadomość i chęć konsumentów do korzystania z produktów przedsiębiorstwa;

- optymalizacja procesów operacyjnych;

- zmniejszenie kosztów produkcji przez wdrażanie nowoczesnych osiągnięć logistyki, poprawy efektywności wykorzystania zasobów i zmniejszenie ilości odpadów;

- możliwości inwestycyjne: zwiększenie atrakcyjności inwestycyjnej i lojalności inwestorów, poprawa dostępu do kapitału;

- zaangażowanie przedsiębiorstwa w system raportowania międzynarodowego rozszerza możliwości uczestnictwa w biznesie międzynarodowym;

- zwiększenie produktywności oraz zapewnienie wykwalifikowanego personelu w przedsiębiorstwie;

- budowanie silnej kultury organizacyjnej (wprowadzenie istotnych wskaźników do oceny efektywności, standardów ładu korporacyjnego i etyki biznesu). 
Istnieją jednak czynniki, które ograniczają aktywność społeczną przedsiębiorstw, a mianowicie:

- niechęć właścicieli do naruszania zasady maksymalizacji zysku;

- koszty potrzeb społecznych są przenoszone na konsumentów w postaci wyższych cen;

- brak kompetencji menedżerów w zakresie odpowiedzialności społecznej oraz niska świadomość społeczna.

Odpowiedzialność społeczna powinna być częścią strategicznych planów przedsiębiorstw w sektorze publicznym i prywatnym. Strategia powinna uwzględniać przepisy krajowe i międzynarodowe oraz priorytety: rozwoju społeczno-gospodarczego, trendów międzynarodowych i najlepszych pomysłów na ich realizację, a także potrzebę rozwoju nowych rynków i pogłębienie istniejących. Strategiczne zarządzanie przedsiębiorstwa odpowiedzialnego społecznie powinno się składać z siedmiu etapów: określenie misji, wizji i wartości przedsiębiorstwa; formułowanie celów i zadań działalności; analiza otoczenia zewnętrznego i wewnętrznego, łącznie z określeniem problemów społecznych i głównych negatywnych skutków działalności przedsiębiorstwa wobec społeczeństwa; analiza alternatywy rozwoju strategicznego; wybór i uzasadnienie strategii; wdrażanie strategii; monitorowanie i ocena realizacji planu strategicznego. W procesie wdrażania strategii z elementami odpowiedzialności społecznej przedsiębiorstwo musi poświęcić dużo uwagi na wspieranie sposobu myślenia przyszłościowego zarówno interesariuszy wewnętrznych, jak i zewnętrznych.

\section{Formułowanie i rozpowszechnianie raportów społecznych przedsiębiorstw}

Więcej informacji na temat działalności społecznej, choć nie zawsze w formie usystematyzowanej, czołowe przedsiębiorstwa (w zasadzie wszystkie) publikują i rozpowszechniają poprzez umieszczanie ich na stronach internetowych; drukowanie prospektów; uczestnictwo w prezentacjach publicznych na imprezach biznesowych (konferencje, forum, lunche biznesowe). Szczególną jednak uwagę należy zwrócić na rozbudowę przestrzeni informacyjnej w celu rozpowszechniania trendów społecznych i wyników przedsiębiorstwa. Ponieważ raportowanie społeczne przedsiębiorstw jest narzędziem pisemnym publicznego informowania akcjonariuszy, pracowników, partnerów i społeczeństwa o tym, w jakim tempie i jakimi metodami przedsiębiorstwo realizuje własną misję i plany strategiczne w obszarach rozwoju gospodarczego społeczeństwa, opieki społecznej i bezpieczeństwa ekologicznego mieszkańców.

Tematy raportu społecznego, jego struktura, proces przygotowania, forma przekazu dowodu raportu do publicznej wiadomości, ocena informacji zwrotnej od ważnych grup odbiorców zależą od charakterystyki gospodarczej działalności przedsiębiorstwa i konkretnej, wybranej strategii komunikacji ze społeczeństwem. Główne etapy formowania i rozprzestrzeniania raportowania społecznego przedsiębiorstw to:

- określanie odpowiedzialności (działu lub grupy roboczej) i formowanie procedury opracowywania i rozpowszechniania raportu społecznego; 
- określanie głównych kwestii, problemów, trendów raportu oraz wskaźników i źródeł informacji;

- określanie interesariuszy wewnętrznych i zewnętrznych;

- zbieranie i analizowanie istotnych informacji;

- przygotowywanie tekstu raportu oraz wdrażanie (jeśli to możliwe) niezależnego procesu oceny jego przygotowania;

- rozpowszechnianie raportu oraz uzyskanie informacji zwrotnej od odbiorców docelowych;

- analiza całego procesu z punktu widzenia skuteczności strategii społecznej, realizacji celów programów socjalnych w praktyce, wpływu na docelowych odbiorców;

- dalsze doskonalenie programów społecznych.

Ze względu na zastosowanie społecznego raportowania przedsiębiorstwo może uzyskać różne korzyści:

- dostarczanie zainteresowanym grupom informacji dotyczącej priorytetowych obszarów aktywności społecznej;

- kreowanie pozytywnego wizerunku i poprawa reputacji przedsiębiorstwa w oczach społeczeństwa, co pobudza popyt na towary znacznie bardziej niż zwykłe tradycyjne kampanie reklamowe;

- aktywizowanie współpracy organizacji pozarządowych i charytatywnych, mających podobne obszary aktywności społecznej.

Należy pamiętać, że raporty powinny zawierać rzetelne informacje na temat pozytywnych i negatywnych skutków działań przedsiębiorstwa. Ponieważ informacja dostarczona będzie traktowana i monitorowana przez różne grupy wpływów (łącznie z międzynarodowymi), staje się również coraz bardziej potrzebna społeczności. Wynika to z faktu, że zwiększa poziom dialogu profesjonalnego między organizacjami gospodarczymi i pozarządowymi w sprawach odpowiedzialności społecznej oraz rozwoju społecznego i gospodarczego w ogóle.

\section{Dyskusja i wnioski}

Przedsiębiorstwa, aby osiągnąć przywództwo na rynku, muszą monitorować potrzeby i oczekiwania interesariuszy, szybko reagować na kwestie społeczne i inicjatywy, ciągle doskonalić jakość decyzji dotyczących zarządzania, generować roczne raporty na temat odpowiedzialności społecznej. Zjawisko odpowiedzialności społecznej, ze względu na stopniowe zmiany cech jakościowych nowoczesnych procesów produkcyjnych, wymaga nowej wiedzy, technologii i gospodarki innowacyjnej. W związku z tym przedsiębiorstwo odpowiedzialne społecznie przechodzi na nowy etap rozwoju. Należy ponadto podkreślić, że zapewnienie przywództwa na rynku poprzez strategię odpowiedzialności społecznej jest ciągłym procesem, wymagającym znacznych środków finansowych.

Odpowiedzialność społeczna opiera się na zasadzie, że tylko wspólne wysiłki mogą prowadzić do sukcesu, dlatego do realizacji niezbędne są następujące środki: 
- wzmocnienie świadomości społecznej na temat znaczenia odpowiedzialności społecznej dla zrównoważonego rozwoju gospodarczego i konkurencyjności przedsiębiorstw przez zwiększenie wiedzy przedsiębiorstw, konsumentów i przedstawicieli rządu na temat potrzeby wdrożenia inicjatyw społecznych;

- stymulacja rozprzestrzeniania niefinansowych raportów przedsiębiorstw, publikacja statystycznej informacji dotyczącej wdrażania praktyk odpowiedzialności społecznej za pośrednictwem wyspecjalizowanych serwisów;

- wspieranie współpracy międzynarodowej w zakresie wymiany doświadczeń i zastosowanie najskuteczniejszych praktyk odpowiedzialności społecznej.

Ogólnie rzecz ujmując, społecznie odpowiedzialne prowadzenie biznesu jest oparte na następujących formach instytucjonalnych: ścisłe przestrzeganie przepisów, wysoka jakość zadowolenia konsumentów, bezpieczeństwo pracy i inwestycji w rozwój człowieka, troska o środowisko naturalne, skuteczne inwestowanie w produkcję, uwzględnienie oczekiwań i opinii zainteresowanych stron, systematyczna budowa zaufanych i wzajemnie korzystnych relacji z interesariuszami na podstawie wymagań dotyczących etyki, wspieranie rozwoju społeczności lokalnych, otwartość i przejrzystość, partnerstwo społeczne w regionach; raportowanie społeczne.

Kierunki kolejnych badań mających na celu zwiększenie społecznej działalności przedsiębiorstw to: określenie nowych form interakcji społecznej w systemie business - rząd - społeczeństwo; uzasadnienie roli gospodarczej odpowiedzialności społecznej w przedsiębiorstwach przy wchodzeniu na rynki światowe; opracowanie strategii społecznej odpowiedzialności.

\section{Bibliografia}

10 Companies with the Best CSR Reputations Access mode, http://www.forbes.com/pictures/ efkk45mmlm/no-10-lego-group-2/\#561b759e4cb9 [dostęp: 17.09.2016].

AA 1000 Account Ability Principles Standard Access mode, http://www.accountability.org/ standards/ [dostęp: 11.08.2016].

Bowen H.R. (1953), Social Responsibilities of the Businessman, Harper and Row, London.

Crane A., McWilliams A., Matten D., Moon J., Siegiel D.S. (red.) (2009), The Oxford Handbook of Corporate Social Responsibility, Oxford University Press, Oxford.

Davis K. (1960), Can business afford to ignore social responsibilities?, „California Management Review", 2, 70-76.

Drexhage J., Murphy D. (2010), Sustainable Development: From Brundtland to Rio 2012, International Institute for Sustainable Development Papers, 19/09.

EU Eco-Management and Audit Scheme, Access mode, http://ec.europa.eu/environment/ emas/index_en.htm [dostęp: 14.08.2016].

Friedman M. (1970), The Social Responsibility of Business is to increase its Profit, „New York Times Magazine", September, 13, 122-126. 
Frynas J.G., Muthuri J.N., Gold S. (2016), SMEs, Corporate Social Responsibility and Sustainability in Supply Chains: An Emerging/Developing Countries Perspective, „Business Ethics: A European Review".

Global Reporting Initiative Access mode, https://www.globalreporting.org/Pages/default. aspx [dostęp: 20.09.2016].

Ihlen O. (2011), The Handbook of Communication and Corporate Social Responsibility, Wiley-Blackwell, New York.

ISO 9000, Quality Management, Access mode, http://www.iso.org/iso/home/standards/management-standards/iso_9000.htm [dostęp: 11.08.2016].

ISO 14000, Environmental management Access mode, http://www.iso.org/iso/home/standards/management-standards/iso14000.htm [dostęp: 11.08.2016].

ISO 26000, Access mode, http://www.iso.org/iso/home/standards/iso26000.htm [dostęp: 11.08.2016].

OHSAS 18001 Occupational Health and Safety Zone Access mode, http://www.ohsas-18001-occupational-health-and-safety.com/ [dostęp: 11.08.2016].

SA 8000, Social Accountability International/SA8000 Standard Access mode, http://www.sa-intl.org/index.cfm?fuseaction=Page.ViewPage\&PageID=937 [dostęp: 11.08.2016].

Teczke J., Buła P., Łyszczarz H., Machaczka K., Żak A., Guja D., Sady M., Sedlak P. (2011), Strategia adaptacji społecznej odpowiedzialności biznesu $w$ okresie społeczno-gospodarczej destabilizacji, projekt nr 2011/03/B/HS4/01972, finansowany przez Narodowe Centrum Nauki w ramach konkursu OPUS 2.

WBCSD - World Business Council for Sustainable Development, Access mode, http://www. wbcsd.org [dostęp: 9.08.2016]. 